\title{
歩車のオキュパンシー指標の提案と住区内街路計画への適用 OCCUPANCY INDICES AND ITS APPLICATION TO PLANNING OF RESIDENTIAL STREETS
}

\author{
塚口博司*.毛利 正光** \\ By Hiroshi TSUKAGUCHI and Masamitsu MŌRI
}

\begin{abstract}
In the planning of residential streets in built-up areas, traffic management technique is essential. Especially in the areas where land readjustment has already put into practice, since fundamental improvement of streets is quite difficult, it is important to assign properly existing space to each transportation means.

From this point of view, by modefying the ordinary occupancy concept in traffic flow, this study proposes new occupancy indices for pedestrians, cycles and vehicles, in order to consider the suitable spatial assignment for individual means. Moreover, the paper shows the examples of applying these indices for the planning of residential streets.

Keywords : residential street, space and time occupancy, local transport planning
\end{abstract}

\section{1. まえがき}

既成住宅地における街路計画にあたっては, 土地区画 整理事業等により街路網の基本形態が一応整っている場 合と, そうでない場合とで対応が異なろう. 後者におい ては街路空間の拡充が焦眉の課題となるが, 前者の場合 には, 既存の道路ストックの有効利用が緊要である.す なわち, 土地区画整備事業等により一定限の街路ストッ クをもつ住居系地区の場合には, 一層の街路空間の拡大 は難しい状況を前提として, 各交通手段に対して既存の 街路空間を適切に割当てていくことが重要であると思わ れる.このような地区の街路に対しては, きめ細かな安 全対策, 快適な歩行環境亡自動車交通に対する適度の利 便性の確保とともに, 各交通主体への空間配分が適切で あるか否かの観点からの検討が重視されるべきであると 考える.このような考え方は, 街路利用主体の合意形成 を図りながら街路整備を行うためにも必要となろう.

従来, 人と車に対する空間配分を検討するための定量 的手法は存在しなかった。 そこで, 本稿は住区内街路に おける歩行者, 自転車および自動車の交通に対する適切

\footnotetext{
* 正会員 工博 大阪大学講師 工学部土木工学科 (元565 吹田市山田丘 2-1)

** 正会員 工博 大阪大学教授 工学部土木工学科(同上)
}

な街路空間配分を検討するために，新たにオキュパン シ一指標を提案し, 若干の適用例を示したものである.

\section{2. オキュパンシー指標の定義}

住区内街路における歩行者, 自動車, 自転車あるいは 二輪車の空間的あるいは時間的占有状況を表現するため には, 交通工学で通常使われているオキュパンシ一の概 念を用いることができよう.ここでは, 歩行者 $(p)$, 自動車 $(c)$, 自転車 $(b)$ の 3 手段について考えること としたい，近年，ミニバイクを中心とした二輪車の増加 が著しい地区があるが, 地区交通における二輪車の位置 付けがいまだ明確にはなっていないと思われるので，本 稿ではこれについては扱っていない.

いま, 住区内街路において数 $10 \mathrm{~m}$ の区間 $l$ を考え, この区間を通行する交通手段 $i(i=p, c, b)$ の $j$ 番 目の交通主体 $i j$ が街路区間 $l$ を通過する時間を $t_{i j}$, 速 度を $v_{i j}$, 占有面積を $A_{i j}$, 交通手段 $i$ の交通量を $q_{i}$, 道路幅員を $d$ とすると, スペースオキュパンシー $Q_{s i}$ は次のように表わせる.

$$
Q_{s i}=\frac{1}{l d} \sum_{j=1}^{n_{i}} A_{i j}
$$

また， $t_{i j}$ と比べて十分に長い時間 $T$ を考えるとき， $t_{i j}$ を用いて区間 $l$ におけるタイムオキュパンシーを表 
わすと次のようである.

$$
Q_{t i}=\frac{1}{T} \sum_{j=1}^{n_{i}} t_{i j}=\frac{1}{T} \sum_{j=1}^{n_{i}} \frac{l}{v_{i j}}
$$

ここで, $v_{i j}$ および $A_{i j}$ の代表值として, 平均值 $\bar{v}_{i}, \bar{A}_{i}$ を用いるとすれば, スペースオキュパンシーに対しては, ある時点において区間に存在する交通主体の数を用い て, $n_{i}=q_{i} l / \bar{v}_{i}$ と考えるのが妥当であろうから，

$$
Q_{s i}=q_{i} \bar{A}_{i} /\left(d \bar{v}_{i}\right)
$$

と表わすことができる.また，夕イムオキュパンシーに 対しては $n_{i}=q_{i} T$ となるから次式が得られる.

$$
Q_{t i}=q_{i} l / \bar{v}_{i}
$$

さて近年，住区内街路においても路上駐車が非常に目 立っている. そこで, 路上駐車車両も含めて自動車の才 キュパンシー指標を表わすことも必要であろう. 区間 $l$ における平均瞬間駐車台数を $\bar{p}(=T$ における駐車車両 の総駐車時間 $/ T)$, 駐車車両が必要とする面積を $A_{p c}$ とすると, 駐車車両のスペースオキュパンシーは, $\left(\bar{p} A_{\rho c}\right)$ $/(l d)$ となる. これと $Q_{s c}$ との和を

$$
Q_{s c}^{*}=Q_{s c}+\left(\bar{p} A_{p c}\right) /(l d)
$$

とすると， $Q_{s c}^{*}$ は路上駐車の影響を考慮した自動車のス ペースオキュパンシー指標であると考えられる. また， タイムオキュパンシーの場合にも同様にして路上駐車の 影響を考慮した指標 $Q_{t c}^{*}$ を求めることができる.

$$
Q_{t c}^{*}=Q_{t c}+\bar{p}
$$

次に, 各交通主体群が占める占有面積および占有時間 の比について考えてみたい。これは， $Q_{s t}$ あるいは $Q_{t i}$ それぞれの比として与えられる. すなわち, 式 $(3)$ より,

$$
\begin{aligned}
& Q_{s p}: Q_{s c}: Q_{s b} \\
& \quad=q_{p} \bar{A}_{\rho} / \bar{v}_{p}: q_{c} \bar{A}_{c} / \bar{v}_{c}: q_{b} \bar{A}_{b} / \bar{v}_{b}
\end{aligned}
$$

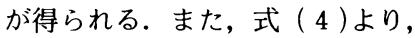

$$
\begin{aligned}
& Q_{t \rho}: Q_{t c}: Q_{t b} \\
& \quad=q_{\rho} / \bar{v}_{p}: q_{c} / \bar{v}_{c}: q_{b} / \bar{v}_{b}
\end{aligned}
$$

が得られる. 式 $(8)$ より上記の $t_{i j}$ に基づいて求めら れたタイムオキュパンシーの構成比は, 各交通手段の密 度比を表わしていることがわかる.

\section{3. オキュパンシー算出のための諸元}

\section{（1）自動車の速度と安全通行面樻}

自動車の走行速度 $\bar{v}_{c}$ は道路交通条件に左右されるか

\begin{tabular}{|c|c|c|c|}
\hline 路目員 & 㮏本数 & 平白 & 保孉伯差 \\
\hline 10（対面通行） & 211 & $34.2 \mathrm{~km} /$ 時 & $0.76 \mathrm{~km} /$ 时 \\
\hline （対面通行） & 168 & 28.6 & 0.88 \\
\hline (一方通行) & 120 & 28.3 & 0.86 \\
\hline （対面通行） & 60 & 23.8 & 2.45 \\
\hline$(一 力 j$ 通行 $)$ & 60 & 25.7 & 0.77 \\
\hline
\end{tabular}
ら, 厳密には個々の場所で実測するか, あるいは各要因 の影響を考慮したモデルの開発が必要となろうが, 次章 での試算には街路幅員別に実测して得た表一1を用いた.

次に, 自動車の安全通行面積 $\bar{A}_{c}$ は, ある速度で走行 している車の前方に歩行者等が突然飛び出したような場 合を想定し, その車が通常の状態で停止できる距離（安 全停止距離）に基づいて求められる.つまり,

安全通行面積 $=($ 安全停止距離 + 自動車の車長 $) \times$ 自

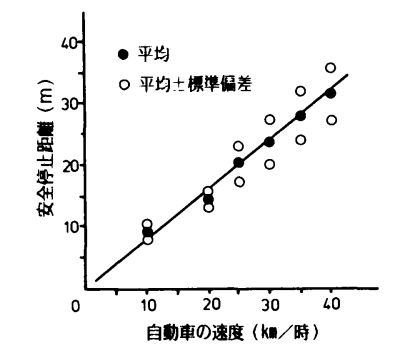

図一1 自动車の速度と安全停止距離

動車の通行幅

と表わした. 安全停止距離については, 実験により走行 速度との関係を図一1のように求めた。自動車の車長と しては実績值に基づいた乗用車の最大車長 $6 \mathrm{~m}$ を用い, 通行幅には道路構造令に定められた車線の最小幅員であ る $2.75 \mathrm{~m}$ を採用した。

\section{（2）自転車の平均速度と通行面積}

自転車の速度は, 地形や利用者の属性等によってかな り変動しようが,ここでは平均的な值として, $\bar{v}_{b}=12$ $\mathrm{km} /$ 時 $^{1)}$ を用いた. 通行幅に対しては, 自転車の走行軌 跡の分析に基づき, 2 台の自転車が擦れ違う際の安全間 隔が $1.7 \mathrm{~m}^{2)}$ とされているので, これに安全車頭間隔と して, 走行速度と車頭間隔の実測值より求められた 7.5 $\mathrm{m}^{3)}$ を乗じて $\bar{A}_{b}=12.8 \mathrm{~m}^{2}$ とした.

\section{（3）平均步行速度と通行面䅪}

著者らは先に, 歩行者交通に関するサービス水準を提 案した .ここでは，ほぼ自由歩行に近い状態として， $\bar{A}_{\rho}=5 \mathrm{~m}^{2} /$ 人 $\left(0.2\right.$ 人 $\left./ \mathrm{m}^{2}\right)$ を採用した。 なお, 歩行速 度は $4 \mathrm{~km} /$ 時とした.

\section{（4）交通量および路上駐車量}

次章では 12 時間にわたって観測された交通量を用い ているが, 検討すべき対象によっては 1 時間程度の短時 間の交通量で差し支えないこともあろう. 路上駐車量に ついては住区内街路における平均的な瞬間駐車台数が求 められればよく,たとえば，いくつかの時間断面で測定 された駐車台数の平均值で表わせばよい.

これらの諸量が得られると, 各地点について $Q_{t i}$, $Q_{s i}$ およびそれぞれの比を求めることができる.

\section{4. オキュパンシー構成比による地区内交通状 況の表現}

以下ではオキュパンシー指標を具体的に求めていく 
が，まず，オキュパンシーの構成比を用いて地区内交通 の状況を表わしてみた．対象地区は，大阪市の住居系地 区である鷹合，加賀屋，高倉，新森，我孫子，今里の 6 地区であり，いずれも土地区画整理済である，各地区で 24 区間（1 地区のみ 28 区間)，合計 148 区間において 道路諸元，手段別交通量等の特性を調査した. 対象とし た道路区間の幅員は $11 \mathrm{~m}, 8 \mathrm{~m}, 6 \mathrm{~m}$ の 3 種類である.

地区内の交通流動については，竹内ら ${ }^{5)}$ がすでに指摘 しているように, 量的には必ずしも厳密にとらえる必要 はなく，各交通手段の構成が問題となることが多い。竹 内らは歩行者, 自動車ならびに自転車の交通量構成比を 三角座標に示して交通特性を分析している.

図一2 は歩行者, 自動車および自転車の交通量構成比

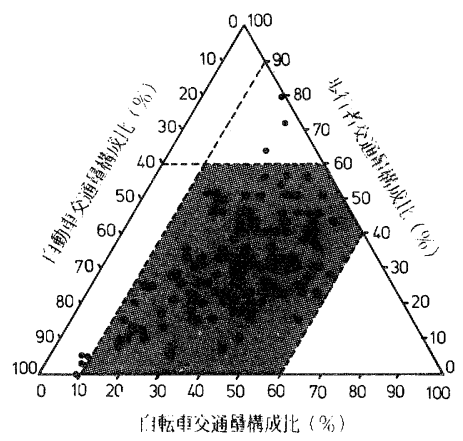

図一2 交通量構成比

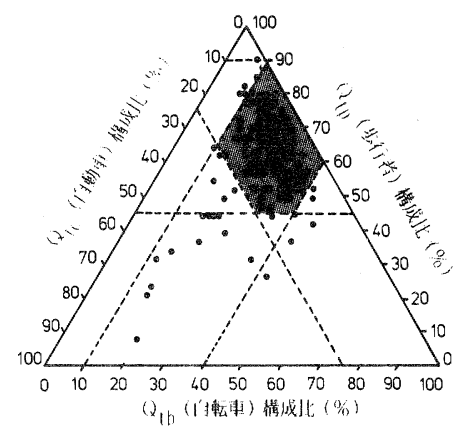

図一3 タイムオキュパンシー $Q_{t i}$ の構成比

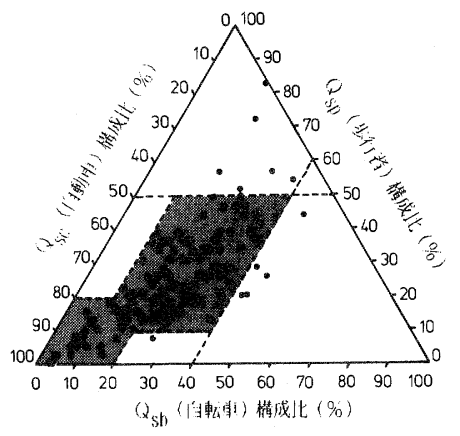

図一4 スペースオキュパンシー $Q_{s i}$ の構成比
を示している，各地点の交通量構成比は非常に広い範囲 に分布している.もっとも上記の研究で指摘されている ように，自転車の範囲はやや狭くなっている．次に同一 データを用いてタイムオキュパンシー構成比を示すと図 一3のようである。各手段が主として存在する範囲を求 めると，自動車が $0 \sim 25 \%$, 自転車が 10 40\%，歩行 者が $45 \sim 90 \%$ の領域に全データの $83 \%$ が含まれてい る.スペースオキュパンシー構成比については図一4の ようであって，おおよそ自転車が $0 \sim 40 \%$ ，歩行者が 0 〜 $50 \%$ 範囲であるのに対し，自動車はほぼ全域に分 布している.なお自転車が $10 \%$ 以下で歩行者が 20 50 \%，および歩行者が $10 \%$ 以下で自転車が 20 ～ $40 \%$ の部 分のようにほとんぞデータが存在しない領域がみられ る。これは, 歩行者亡自転車の占有空間の一方がある程 度大きければ,他方も小さくはないことを表わしている.

このように，オキュパンシー構成比で表わすと，交通 量構成比で表わすよりもデータが存在する領域が限定さ れてくるが，一方で，その領域をはずれた地点の特徴を 明確にすることができる．すなわち図一3からは，上記 の領域外で自動車オキュパンシー構成比 $25 \%$ 以上の地 点の大部分は，幅員 $11 \mathrm{~m}$ 以上で地区の骨組みとなる道 路であり，自動車交通に特化した道路区間であるといえ る.また，図一4で歩行者オキュパンシー構成比 $50 \%$ 以上の道路区間には商店の立地が多く歩行者交通に特化 した区間であるといえる.さらに, 夕イムオキュパンシー 構成比とスペースオキュパンシー構成比で表わすのでは 差が非常に大きく，住区内街路においては空間的に自動 車の占有の程度が高いが, 時間的には歩行者の占有の程 度が高いという利用実態が明確に表わされている。

\section{5. 住内区街路計画への適用}

\section{（1）はじめに}

交通手段間の空間配分バランスを考える場合，現に各 手段に割り当てられている空間，たとえば車道や歩道の 面積や延長の比率を指標（街路ストック指標）とするこ とができる，一方，各手段が実際に使用している空間や 時間の比率に基づいた指標（街路利用指標）が考えられ る.オキュパンシー指標はこのような指標の 1 つである. 住区内街路の合理的運用について検討する際に，ストッ ク指標とオキュパンシー指標の乘離を小さくすることが 1 つの望ましい姿を与えているといえよう.もっとも, 住区内街路においては歩行者交通が重視されるべきであ るから, 歩行者に関するストック指標がオキュパンシー 指標を若干上まわっても差し支えないと考える.

また，オキュパンシー指標と住民の居住環境評価意識 との関係を調べ,これより求められる種々の許容限界值 を街路計画に適用することができよう. 
以下では，スペースオキュパンシー指標の街路計画へ の適用事例について述べることにしたい。

（2）街路ストック指標と街路利用指標との比較

一例として歩車道の幅員配分比率についての検討事例 を示すここでは，自動車と，歩行者および自転車の空 間の比率について考えることとしたい．前章と同一の データを用いて，自動車のスペースオキュパンシー指標 の構成比の分布状況を幅員別に示すと図一5 のようであ る. たとえば, $11 \mathrm{~m}$ 街路に $2.5 \mathrm{~m}$ の両側歩道を設置し た場合，ストック指標である車道幅員比率は 0.55 であ る. 図一5を用いて歩車の空間配分比率の適否を判断す ると，このような整備は住区内街路の性格からみて妥当 であると思われる。一方, $8 \mathrm{~m}$ 街路に $2 \mathrm{~m}$ の両側歩道を 設置する場合 (車道幅員比率：0.50) や，6 $\mathrm{m}$ 街路に 2 $\mathrm{m} の$ 片側歩道を設置する場合（車道幅員比率：0.67） には, 自動車に対するストック指標がオキュパンシー構 成比を上まわっていることが多く, 歩行者等に対する空 間をさらに拡充させていくべき場合があると思われる。 なおここでは歩車分離することを前提として考えたが， 本稿は住区内街路において歩車道の完全分離が望ましい と主張するものではない，幅員構成とともに分離の適否 について検討する場合には，たとえば著者らが先に提案 した基準 ${ }^{6}$ 等を合わせて用いることになる.また,オキュ パンシー指標は, コミュニティ道路等の断面構成を検討 する際にも原則的に適用可能であると考えられる.

さらに,やや概念を拡げ, 地区における歩行者空間 (歩 行者系施設) と自動車空間（自動車系施設）上の適正な 配分の検討にも利用できよう.ただし, 街路区間単位で の指標を地区レベルでの表現に改める必要がある.

（３）オキュパンシー指標に許容値を設定できる場合

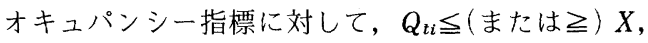

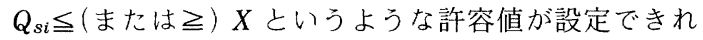
ば,これを用いて空間配分について論じることができる.

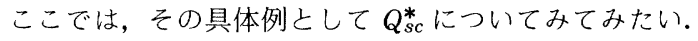
図一6は $Q_{s c}^{*}$ と歩行者の安全意識との関係を示してい る. 安全性評価「ふつう」を目安とするとすれば，許容 值 $X$ の值を求めることができる.これを用いれば,

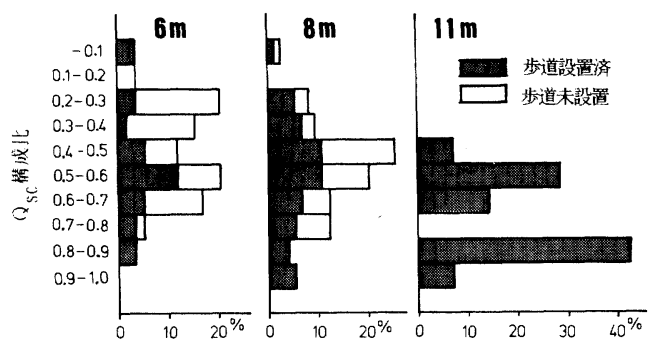

図一5 街路幅員別にみた $Q_{s c}$ 構成比の分布

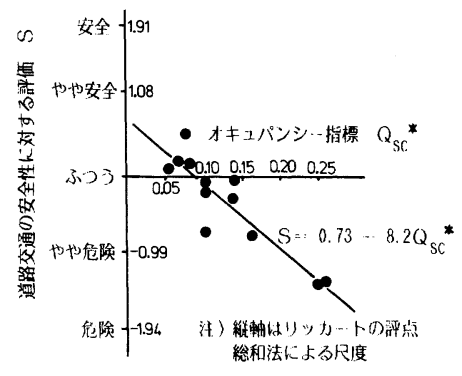

図一6 オキュパンシー指標と安全性評価

$q_{c} \bar{A}_{c} /\left(d \bar{v}_{c}\right)+\left(\bar{p} A_{p c}\right) /(l d) \leqq 0.09$

より, 自動車交通量と街路幅員に応じて, 住区内街路に おける許容駐車台数を求めることができる71.この手法 には, 自動車交通量と駐車量を同時にとらえられる利点 があるが, 自動車交通量の許容限界については交通処理 の側面からも別途検討する必要があろう.

\section{6. むすび}

本稿では歩車のオキュパンシーの概念を住区内街路計 画に適用することを提案したが, 若干の留意点を付記し ておきたい，歩行者のオキュパンシーの程度に応じて歩 行者空間整備を行うとするならば，一般にこの值が大き い方が歩行者にとって望ましい，ところで，本稿で用い た実測デー夕に基づけば，交通量が一定の場合，自動車 の速度が大きくなると自動車のスペースオキュパンシー は小さくなる，このため，歩行者や自転車のスペースオ キュパンシー構成比は相対的に大きくなる.したがって, 地区における種々の交通対策を比較するにあたって，自 動車の速度に変化が生じる場合には，オキュパンシー指 標の変動に対する解粕に注意することが必要であろう.

最後に，本研究を進めるにあたりご助言を頂いた近畿 大学理工学部 三星昭宏講師, 大阪大学工学部 山田 稔 助手，ならびに調査，分析に協力頂いた大阪大学学生 山田順一君（現大阪府土木部）に深謝の意を表したい。

\section{参 考 文 献}

1）交通工学研究会：交通工学ハンドブック,pp.114.

2）高岸節夫：自転車道の通行帯幅員に関する一実験的考察, 交通工学, Vol.12, No.6, 1977.

3）日本道路協会：自転車道等の設計基準解説，1974.

4）毛利正光・塚口博司：歩行路における歩行者挙動に関す る研究, 土木学会論文報告集, No. 268, 1977.

5）竹内伝史ほか：住区内街路における交通量の推計方法に ついて, 国際交通安全学会誌, Vol. 5, No.1, 1979.

6）毛利正光・塚口博司：住区内道路における歩道整備に関 する基礎的研究，土木学会論文報告集，No. 304, 1980.

7）塚口博司：住区内街路における駐車現象の分析と街路運 用に関する研究, 土木計画学研究・論文集, No. 4, 1986.

(1986.12.4 · 受付) 